\title{
Legionella pneumophila in cooling water systems
}

\author{
Report of a survey of cooling towers in London and \\ a pilot trial of selected biocides
}

\author{
BY J. B. KURTZ
}

Virology and Public Health Laboratory, John Radcliffe Hospital, Oxford OX3 9DU

C. L. R. BARTLETT

Communicable Disease Surveillance Centre, Colindale, London NW9 $5 E Q$

\author{
U. A. NEWTON, R. A. WHITE \\ Technical Division, Houseman (Burnham) Ltd., Slough SL1 7 LS
}

AND N. L. JONES

Environmental Services, London NW2 3ST

(Received 22 January 1982; accepted 15 February 1982)

\section{SUMMARY}

Fourteen recirculating cooling water systems were surveyed during the summer, 1981, to see what factors might influence the prevalence of Legionella pneumophila. The effect on the organism of three anti-microbials was studied, each in two systems, by intermittent treatment at two week intervals.

L. pneumophila was isolated from six of the 14 cooling systems at the beginning of the trial but by the end was present in ten. An association was found between the presence of the organism and the concentration of dissolved solids, and chlorides and the $\mathrm{pH}$. There also appeared to be associations with exclusion of light and higher water temperatures.

Repeated tests on eight untreated systems showed that two were consistently infected, three became and remained infected, one was infected on a single occasion and two were never infected with $L$. pneumophila. Treatment of a contaminated system, either with a 10 p.p.m mixture of a quaternary ammonium compound and tributyltinoxide or slow release chlorine briquettes (maximum recorded free chlorine level 1.2 p.p.m.), did not eliminated legionellae. Treatment of two infected towers with a chlorinated phenol (100 p.p.m.) eliminated legionellae for at least three days, but after 14 days the organism was again found. 


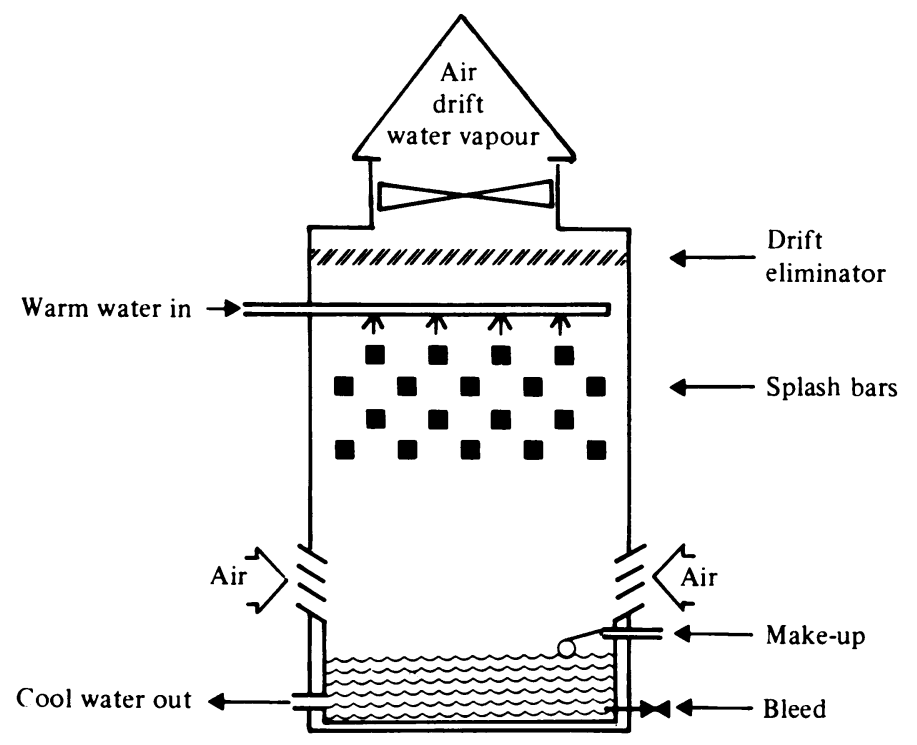

Fig. 1. Schematic diagram of a cooling tower.

\section{INTRODUCTION}

Legionella pneumophila, the bacterium responsible for the epidemic of pneumonia in Philadelphia, U.S.A. in 1976, has since been shown to have caused similar epidemics and sporadic infections in many parts of the world. Environmental surveys in this country and the U.S.A. indicate that the organism is widespread in nature. It has been recovered from mud, rivers, lakes and other natural collections of water (Morris et al. 1979; Fliermans et al. 1979; Fliermans et al. 1981) and it is clear that the bacterium is also present in man-made water systems. It has been found in domestic water and recirculating cooling water systems (Morris et al. 1979; Tobin, Swann and Bartlett, 1981 ; Cordes et al. 1981). The importance of each as a source of $L$. pneumophila infections is not known but the prevalence of the bacterium in cooling water systems makes them important potential sources. There is also epidemiological evidence from the United States that such systems have been the source of outbreaks of Legionnaires' disease (Dondero et al. 1980; Band et al. 1981). The infection is acquired by inhaling the aerosol generated by cooling towers or evaporative condensers.

Cooling towers and evaporative condensers are devices designed to cool water and dissipate unwanted heat to the atmosphere. They are usually located on the roofs of buildings which they serve as part of the air-conditioning system. Warm water from the building's heat exchanger enters the tower near the top and is sprayed down over splash bars or honeycomb packing, usually made of wood or plastic (Fig. 1).

As the droplets pass down the tower they partially evaporate, cooling the 
remaining water. The cooled water collects in a pond at the base of the tower and is recirculated through pipework to the heat exchanger. In order to achieve maximum cooling, air is drawn up through the falling droplets by a fan. Approximately $1 \%$ of the recirculated water is lost by evaporation, as a result of which, inorganic and organic material is concentrated in the system. To minimize this build-up, water is continuously drained, 'bled off', from the pond. A smaller proportion (approximately $0.1 \%$ ) escapes in the form of small droplets, 'drift', and these will contain any micro-organisms and impurities present. All these losses are made up by the addition of fresh water.

In such a complex system many environments exist which may be suitable for the growth of algae, protozoa and bacteria in a variety of symbiotic relationships. The deposition of salts and debris and the production of slime by the microbes all reduce the efficiency of the system. Practical measures should therefore be taken in the design, siting and maintenance of cooling water towers to prevent or minimize these factors.

We have studied a group of cooling water systems to see what factors might favour the presence of $L$. pneumophila and whether various disinfection regimens would influence this.

\section{METHODS}

\section{Initial survey of cooling towers}

Fourteen cooling towers, located in London, were studied. They were examined in the spring of 1981 to assess the following: the volume of water in the systems, material used in construction, whether the towers were exposed to light, the presence of visible algae, the state of maintenance and condition of fabric. At the same time water samples were taken for chemical analysis, total bacterial counts, and to look for the presence of $L$. pneumophila and amoebae.

\section{Chemical analysis of the water}

Standard methods (Department of the Environment, 1972) were used to estimate free $\mathrm{CO}_{2}$, total hardness, carbonate hardness, non-carbonate hardness, fluorides, nitrate, sulphate, silica, calcium, magnesium, free and combined ammonia as $\mathrm{NH}_{3}$, albuminoid ammonia, iron in suspension and in solution, and copper in suspension and in solution.

\section{Total bacterial counts}

Bacterial counts were determined by a dilution plate count technique. One ml of serial 10-fold dilutions of the water sample was mixed with $15 \mathrm{ml}$ nutrient agar held at $45^{\circ} \mathrm{C}$. Pour plates were made and incubated at $30^{\circ} \mathrm{C}$. Colonies were counted after $48 \mathrm{~h}$.

Isolation of $\mathrm{L}$. pneumophila

A $5 \mathrm{l}$ sample of water was passed through a $0.3 \mu \mathrm{m}$ pore size membrane. The filtered matter on the membrane was then resuspended in $20 \mathrm{ml}$ of the filtrate by 
vigorous shaking. Five $\mathrm{ml}$ of this suspension was inoculated intraperitoneally (i.p.) into each of two 6-week-old guinea pigs. The animals' temperatures were recorded daily for a week. Blood cultures were taken by cardiac puncture on the third and fourth day after inoculation and plated directly onto Aces buffered charcoal yeast extract (CYE) medium (Pasculle et al. 1980). Peritoneal fluid and splenic cultures were made from any animal that was very sick or found dead during the period of observation. Cultured bacteria were identified as L. pneumophila by immunofluorescent microscopy using antisera against L. pneumophila serogroups 1-6 (kindly supplied by Dr A. G. Taylor, Division of Microbiological Reagents and Quality Control, Colindale) and by gas-liquid chromatography (kindly performed by Dr J. Gilbart, Bacterial Metabolism Research Laboratory, Colindale).

\section{Isolation of amoebae}

A drop (0.025 ml) of the suspension used for L. pneumophila isolation was plated onto non-nutrient agar which had previously been spread with a lawn of $E$. coli. The plates were incubated in a moist environment at $27^{\circ} \mathrm{C}$ and observed three times per week for two weeks. Wet preparations of any amoebae seen were made in Page's saline, examined by phase contrast microscopy and classified to the level of the genus.

\section{Trial of biocides}

\section{Selection of biocides}

Anti-microbials were chosen from three different chemical groups. (1) QAC/TBTO, a quaternary ammonium compound dimethyl-didecyl ammonium chloride $(45 \%)$ /tributyltinoxide (5\%) mixture (Hatacide LP2, Houseman (Burnham) Ltd.). American reports (Skaliy et al. 1980; Grace et al. 1981) had shown that a QAC was very active against $L$. pneumophila and that this activity was enhanced by TBTO, the mixture having cidal activity at 2 parts per million (p.p.m.). (2) $\mathrm{CPh}$, a biodegradable chlorinated phenolic thio-ether $(40 \%)$ with an antifoaming agent (Hatacide LP5, Houseman (Burnham) Ltd.) (3) SCl, a slow release chlorine preparation, sodium di-chlor-isocyanurate. The bacterium is inhibited by exposure for $1 \mathrm{~h}$ to 0.65 p.p.m. hypochlorite, (Wang et al. 1979) but after bolus treatment of a cooling tower with 5 p.p.m. free chlorine, detectable levels of chlorine persisted for less than $8 \mathrm{~h}$. (Fisher-Hoch et al. 1981).

\section{Laboratory tests of biocides}

L. pneumophila serogroup I was used as the test organism. A freshly isolated strain (guinea pig spleen suspension) was inoculated into yolk sacs of fertile hen eggs. After 4 days incubation the yolk sacs were harvested and stored at $-70^{\circ} \mathrm{C}$. To test a disinfectant, yolk sac material was plated onto buffered CYE medium and incubated $3-4$ days at $37^{\circ} \mathrm{C}$. The bacterial growth obtained was checked for purity, scraped off, and suspended in sterile boiled water. Dilutions of the disinfectant under test were made in $99 \mathrm{ml}$ volumes of sterile boiled water and $1 \mathrm{ml}$ of the thick bacterial suspension was added and mixed well. Immediately $(0 \mathrm{~h})$ and after 1,3 and $6 \mathrm{~h}, 1 \mathrm{ml}$ of the mixture was drawn off, serial 10 -fold dilutions were 
made and quantitative plate counts (Miles \& Misra, 1938) performed on phosphate or Aces buffered CYE medium. Colony counts were made after 4 days incubation at $37^{\circ} \mathrm{C}$.

\section{The trial}

It was decided, following the early laboratory tests, to treat cooling systems to achieve levels, $4 \mathrm{~h}$ after treatment, of 10 p.p.m. QAC/TBTO or 100 p.p.m. CPh. The aim for chlorination was for a continuous level of 0.5-2 p.p.m. free chlorine. The dose of chemical was calculated with reference to the effective capacity of the system, that is the actual capacity plus the volume of fresh 'make-up' water added to the system over $4 \mathrm{~h}$. This ensured that the concentration of the biocide was maintained at or above the selected level for at least $4 \mathrm{~h}$.

On the basis of the initial survey the 14 cooling towers were allocated to one of three treatment groups or a control group. An attempt was made to match treated and control systems according to capacity, type of construction, degree of 'bleed-off' and presence or absence of $L$. pneumophila. The three anti-microbials were tested each in two towers throughout the summer season. The frequency of treatment was once every two weeks, an interval selected because of its feasibility as a routine procedure. The regimen was strictly followed throughout the trial with the exception that to the $\mathrm{SCl}$ treated systems a fast release chlorine preparation (sodium tri-chlorisocyanurate) was added to the last two treatments. The eight control systems were used to study any natural seasonal variations. No anti-scale or anti-corrosion treatment was permitted during the triab in order to reduce the number of variables affecting the growth of microbes.

Every two weeks water samples were taken from all the cooling towers for bacterial counts. From those that were being treated these were taken immediately before and $\frac{1}{2} \mathrm{~h}$ after treatment. The water temperature was recorded and the $\mathrm{pH}$ measured. Free chlorine was estimated using a Lovibond DTB comparator; total dissolved solids were measured with a conductivity meter and chlorides assayed by the standard silver nitrate method. Additional samples were taken three times during the summer to monitor the water chemistry and for L. pneumophila isolation. The first of these samples was collected six weeks after the start of the trial immediately prior to the fourth biocide treatment, with the exception of the sample from system $\mathrm{E}$ that was taken seven days after the third treatment. The second and third samples were collected three days and 14 days respectively after the final treatment in week 12.

\section{RESULTS}

L. pneumophila was detected in six of the 14 cooling systems in the initial survey in April/May 1981. It was not possible to measure the numbers present by the isolation method used. It must also be remembered that the sensitivity of the technique was limited by the minimal guinea pig infective dose (i.p.) that resulted in bacteraemia or sickness. The organism was always subsequently found in four of these initially 'positive' towers but in the two others, both treated with $\mathrm{CPh}$, 


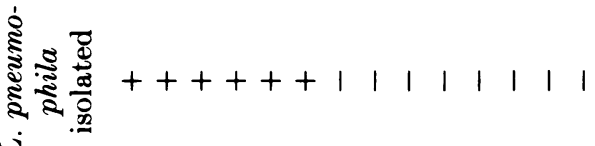

$$
\begin{aligned}
& \checkmark
\end{aligned}
$$

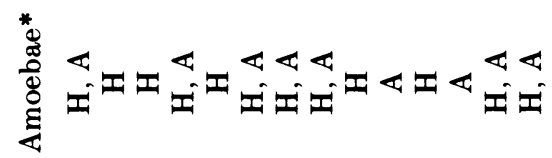

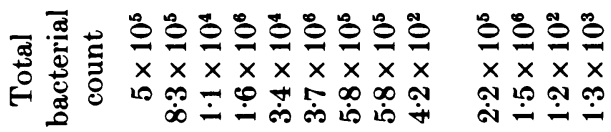

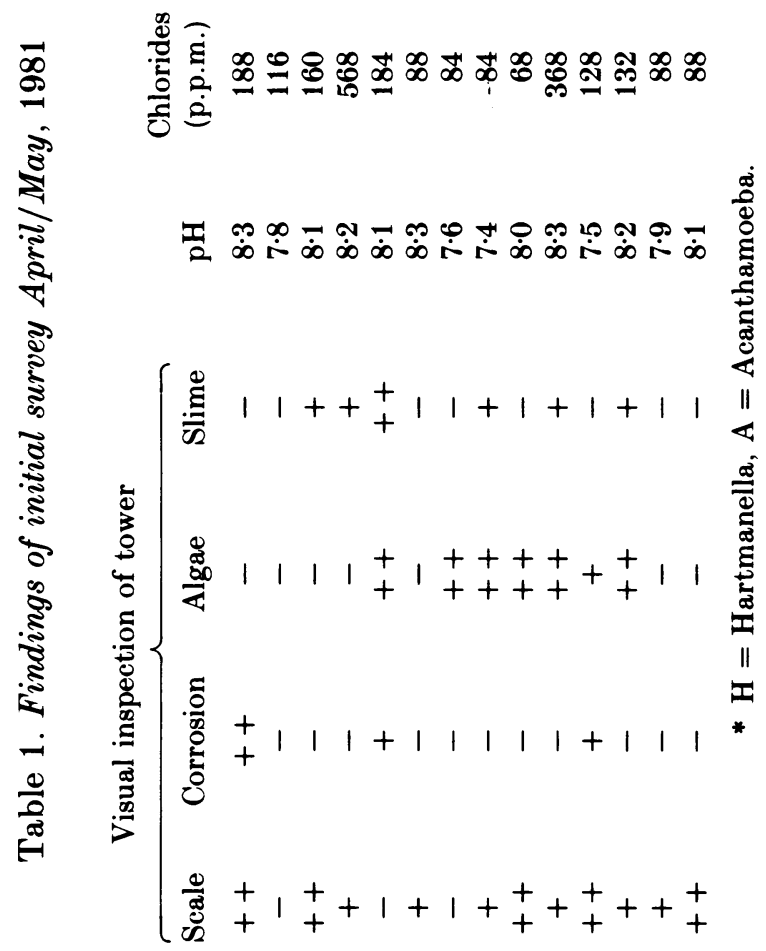

อิ 然要

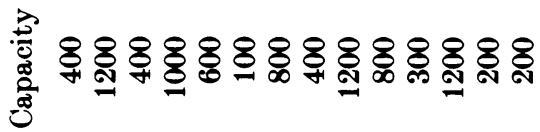

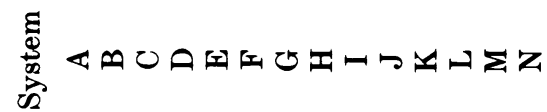


Table 2. Cooling systems from which $\mathrm{L}$. pneumophila was consistently isolated Total bacterial

count

\begin{tabular}{|c|c|c|c|c|c|c|c|c|}
\hline System & $\begin{array}{l}\text { Treatment } \\
\text { group }\end{array}$ & Sample & $\begin{array}{l}\text { L. pneu- } \\
\text { mophila } \\
\text { isolated }\end{array}$ & $\begin{array}{c}\text { Pre- } \\
\text { treatment }\end{array}$ & $\begin{array}{c}\text { Post- } \\
\text { treatment }\end{array}$ & $\mathrm{pH}$ & $\begin{array}{c}\text { Tempera- } \\
\text { ture } \\
\left({ }^{\circ} \mathrm{C}\right)\end{array}$ & $\begin{array}{c}\text { Chlorides } \\
\text { (p.p.m.) }\end{array}$ \\
\hline A & QAC/TBTO & $\begin{array}{l}1 \\
2 \\
3\end{array}$ & $\begin{array}{l}+ \\
+ \\
+\end{array}$ & $\begin{array}{l}10^{6} \\
10^{5} \\
10^{5}\end{array}$ & $\begin{array}{l}10^{6} \\
10^{5} \\
10^{5}\end{array}$ & $\begin{array}{l}8 \cdot 0 \\
8 \cdot 0 \\
8 \cdot 2\end{array}$ & $\begin{array}{l}25 \\
23 \\
25\end{array}$ & $\begin{array}{l}760 \\
550 \\
.700\end{array}$ \\
\hline B & $\mathrm{SCl}$ & $\begin{array}{l}1 \\
2 \\
3\end{array}$ & $\begin{array}{l}+ \\
+ \\
+\end{array}$ & $\begin{array}{l}10^{6} \\
10^{5} \\
10^{6}\end{array}$ & $\begin{array}{l}10^{3} \\
<1 \\
<1\end{array}$ & $\begin{array}{l}7 \cdot 8 \\
8 \cdot 0 \\
8 \cdot 1\end{array}$ & $\frac{22}{-}$ & $\begin{array}{l}260 \\
180 \\
330\end{array}$ \\
\hline $\mathrm{C}$ & Control & $\begin{array}{l}1 \\
2 \\
3\end{array}$ & $\begin{array}{l}+ \\
+ \\
+\end{array}$ & $\begin{array}{l}10^{4} \\
10^{4} \\
10^{3}\end{array}$ & $\begin{array}{l}\text { N/A } \\
\text { N/A } \\
\text { N/A }\end{array}$ & $\begin{array}{l}8 \cdot 0 \\
8 \cdot 1 \\
7 \cdot 9\end{array}$ & $\begin{array}{l}26 \\
16 \\
25\end{array}$ & $\begin{array}{r}110 \\
90 \\
80\end{array}$ \\
\hline D & Control & $\begin{array}{l}1 \\
2 \\
3\end{array}$ & $\begin{array}{l}+ \\
+ \\
+\end{array}$ & $\begin{array}{l}10^{5} \\
10^{5} \\
10^{5}\end{array}$ & $\begin{array}{l}\text { N/A } \\
\text { N/A } \\
\text { N/A }\end{array}$ & $\begin{array}{l}7 \cdot 8 \\
8 \cdot 0 \\
8 \cdot 3\end{array}$ & $\begin{array}{l}19 \\
20 \\
19\end{array}$ & $\begin{array}{l}260 \\
200 \\
480\end{array}$ \\
\hline
\end{tabular}

Table 3. Cooling systems from which L. pneumophila was not consistently isolated Total bacterial count

\begin{tabular}{|c|c|c|c|c|c|c|c|c|}
\hline \multirow[b]{2}{*}{ System } & \multirow[b]{2}{*}{$\begin{array}{l}\text { Treatment } \\
\text { group }\end{array}$} & \multirow[b]{2}{*}{ Sample } & \multirow{2}{*}{$\begin{array}{l}\text { L. pneu- } \\
\text { mophila } \\
\text { isolated }\end{array}$} & & & \multicolumn{2}{|r|}{ Tempera- } & \multirow[b]{2}{*}{$\begin{array}{l}\text { Chloride } \\
\text { (p.p.m.) }\end{array}$} \\
\hline & & & & $\begin{array}{c}\text { Pre- } \\
\text { treatment }\end{array}$ & $\begin{array}{c}\text { Post- } \\
\text { treatment }\end{array}$ & $\mathrm{pH}$ & $\begin{array}{l}\text { ture } \\
\left({ }^{\circ} \mathrm{C}\right)\end{array}$ & \\
\hline$E^{*}$ & $\mathrm{CPh}$ & $\begin{array}{l}1 \\
2 \\
3\end{array}$ & $\begin{array}{l}- \\
\bar{t}\end{array}$ & $\begin{array}{l}10^{5} \\
10^{4} \\
10^{4}\end{array}$ & $\begin{array}{l}10^{5} \\
10^{6} \\
10^{4}\end{array}$ & $\begin{array}{l}8 \cdot 1 \\
8 \cdot 0 \\
8 \cdot 0\end{array}$ & $\begin{array}{l}21 \\
22 \\
18\end{array}$ & $\begin{array}{l}70 \\
40 \\
60\end{array}$ \\
\hline$F^{*}$ & $\mathrm{CPh}$ & $\begin{array}{l}\mathbf{1} \\
\mathbf{2} \\
\mathbf{3}\end{array}$ & $\begin{array}{l}+ \\
+ \\
+\end{array}$ & $\begin{array}{l}10^{5} \\
10^{6} \\
10^{6}\end{array}$ & $\begin{array}{l}10^{2} \\
10^{1} \\
10^{4}\end{array}$ & $\begin{array}{l}7 \cdot 8 \\
7 \cdot 5 \\
7 \cdot 8\end{array}$ & $\begin{array}{l}19 \\
23 \\
19\end{array}$ & $\begin{array}{r}50 \\
210 \\
210\end{array}$ \\
\hline $\mathrm{G} \dagger$ & Control & $\begin{array}{l}1 \\
2 \\
3\end{array}$ & $\begin{array}{l}- \\
+ \\
+\end{array}$ & $\begin{array}{l}10^{3} \\
10^{4} \\
10^{5}\end{array}$ & $\begin{array}{l}\text { N/A } \\
\text { N/A } \\
\text { N/A }\end{array}$ & $\begin{array}{l}7 \cdot 0 \\
7 \cdot 5 \\
8 \cdot 1\end{array}$ & $\begin{array}{l}25 \\
21 \\
11\end{array}$ & $\begin{array}{l}90 \\
70 \\
50\end{array}$ \\
\hline $\mathbf{H} \dagger$ & Control & $\begin{array}{l}\mathbf{1} \\
\mathbf{2} \\
\mathbf{3}\end{array}$ & $\begin{array}{l}- \\
+ \\
+\end{array}$ & $\begin{array}{l}10^{3} \\
10^{5} \\
10^{4}\end{array}$ & $\begin{array}{l}\text { N/A } \\
\text { N/A } \\
\text { N/A }\end{array}$ & $\begin{array}{l}7 \cdot 0 \\
7 \cdot 5 \\
7 \cdot 8\end{array}$ & $\begin{array}{l}22 \\
18 \\
12\end{array}$ & $\begin{array}{r}70 \\
490 \\
470\end{array}$ \\
\hline $\mathrm{I} \dagger$ & Control & $\begin{array}{l}\mathbf{1} \\
\mathbf{2} \\
\mathbf{3}\end{array}$ & $\begin{array}{l}+ \\
+ \\
+\end{array}$ & $\begin{array}{l}10^{6} \\
10^{6} \\
10^{5}\end{array}$ & $\begin{array}{l}\text { N/A } \\
\text { N/A } \\
\text { N/A }\end{array}$ & $\begin{array}{l}7 \cdot 9 \\
8 \cdot 1 \\
8 \cdot 0\end{array}$ & $\begin{array}{l}23 \\
17 \\
18\end{array}$ & $\begin{array}{r}125 \\
60 \\
70\end{array}$ \\
\hline J† & Control & $\begin{array}{l}1 \\
2 \\
3\end{array}$ & $\begin{array}{l}- \\
+ \\
-\end{array}$ & $\begin{array}{l}10^{4} \\
10^{4} \\
10^{4}\end{array}$ & $\begin{array}{l}\text { N/A } \\
\text { N/A } \\
\text { N/A }\end{array}$ & $\begin{array}{l}7 \cdot 9 \\
8 \cdot 2 \\
7 \cdot 9\end{array}$ & $\begin{array}{l}21 \\
23 \\
22\end{array}$ & $\begin{array}{l}380 \\
115 \\
100\end{array}$ \\
\hline
\end{tabular}

* Cooling systems from which $L$ pneumophila was isolated in the initial survey but not consistently during the trial.

$\dagger$ L. pneumophila was not isolated initially but was found during the trial. 
Table 4. Cooling systems from which L. pneumophila was never isolated

\begin{tabular}{|c|c|c|c|c|c|c|c|c|}
\hline \multirow[b]{2}{*}{ System } & \multirow[b]{2}{*}{$\begin{array}{l}\text { Treatment } \\
\text { group }\end{array}$} & \multirow[b]{2}{*}{ Sample } & \multicolumn{3}{|c|}{$\begin{array}{c}\text { Total bacterial } \\
\text { count }\end{array}$} & \multirow[b]{2}{*}{$\mathrm{pH}$} & \multirow[b]{2}{*}{$\begin{array}{c}\text { Tempera- } \\
\text { ture } \\
\left({ }^{\circ} \mathrm{C}\right)\end{array}$} & \multirow[b]{2}{*}{$\begin{array}{c}\text { Chlorides } \\
\text { (p.p.m.) }\end{array}$} \\
\hline & & & $\begin{array}{l}\text { L. pneu- } \\
\text { mophila } \\
\text { isolated }\end{array}$ & $\overbrace{\begin{array}{c}\text { Pre- } \\
\text { treatment }\end{array}}$ & $\begin{array}{l}\text { Post- } \\
\text { treatment }\end{array}$ & & & \\
\hline $\mathbf{K}$ & QAC/TBTO & $\begin{array}{l}1 \\
2 \\
3\end{array}$ & $\begin{array}{l}- \\
- \\
-\end{array}$ & $\begin{array}{l}10^{5} \\
10^{6} \\
10^{5}\end{array}$ & $\begin{array}{l}10^{5} \\
10^{6} \\
10^{4}\end{array}$ & $\begin{array}{l}7 \cdot 8 \\
8 \cdot 3 \\
8 \cdot 1\end{array}$ & $\begin{array}{l}16 \\
20 \\
19\end{array}$ & $\begin{array}{r}140 \\
590 \\
90\end{array}$ \\
\hline $\mathbf{L}$ & $\mathrm{SCl}$ & $\begin{array}{l}1 \\
2 \\
3\end{array}$ & $\begin{array}{l}- \\
- \\
-\end{array}$ & $\begin{array}{l}10^{5} \\
10^{4} \\
10^{4}\end{array}$ & $\begin{array}{l}10^{5} \\
<1 \\
<1\end{array}$ & $\begin{array}{l}7 \cdot 9 \\
8 \cdot 0 \\
8 \cdot 2\end{array}$ & $\begin{array}{l}18 \\
21 \\
25\end{array}$ & $\begin{array}{r}120 \\
65 \\
60\end{array}$ \\
\hline $\mathbf{M}$ & Control & $\begin{array}{l}1 \\
2 \\
3\end{array}$ & $\begin{array}{l}- \\
- \\
-\end{array}$ & $\begin{array}{l}10^{4} \\
10^{4} \\
10^{5}\end{array}$ & $\begin{array}{l}\text { N/A } \\
\text { N/A } \\
\text { N/A }\end{array}$ & $\begin{array}{l}7 \cdot 0 \\
7 \cdot 5 \\
7 \cdot 6\end{array}$ & $\begin{array}{l}15 \\
18 \\
14\end{array}$ & $\begin{array}{r}50 \\
90 \\
110\end{array}$ \\
\hline $\mathbf{N}$ & Control & $\begin{array}{l}1 \\
2 \\
3\end{array}$ & $\begin{array}{l}- \\
- \\
-\end{array}$ & $\begin{array}{l}10^{4} \\
10^{3} \\
10^{5}\end{array}$ & $\begin{array}{l}\text { N/A } \\
\text { N/A } \\
\text { N/A }\end{array}$ & $\begin{array}{l}7 \cdot 0 \\
7.5 \\
7.9\end{array}$ & $\begin{array}{l}18 \\
18 \\
13\end{array}$ & $\begin{array}{r}350 \\
90 \\
100\end{array}$ \\
\hline
\end{tabular}

it was not detected within seven days of treatment. During the summer legionellae were also found in four of the eight initially 'negative' towers. All legionellae isolated gave GLC patterns characteristic of $L$. pneumophila and were grouped by immunofluorescence as serogroup 1. No other species within the family Legionellaceae were identified.

No clear relationship was seen between the capacity of the system and the presence of $L$. pneumophila although three of the four small systems were in the 'negative' group (Table 1). Most of the cooling towers were of open design but the three in which light was excluded all harboured legionellae. There was no obvious association between the presence of $L$. pneumophila and degree of scaling or corrosion. Algae were only seen in one of the six systems which were initially 'positive' but from six of the eight systems which were 'negative' and slime was seen as frequently in systems with or without legionellae. Total bacterial counts ranged between $10^{2}$ and $10^{6}$ and tended to be higher in systems with legionellae.

Results of $L$. pneumophila isolation from the three water samples collected from each of the systems during the trial are shown in Tables $2,3 \& 4$. In Table 2 are given total bacterial counts, $\mathrm{pH}$, temperatures and chloride concentrations for the systems from which L. pneumophila were isolated during the initial survey and throughout the trial. Table 3 gives similar values for the intermediate group of systems which were positive on occasions either during the survey or later in the trial. Table 4 gives the results for the four towers which were consistently negative.

Isolations of legionellae from the untreated systems followed three patterns; two were consistently 'positive' (C, D), four. (G-J) were 'negative' at first but became 'positive' during the summer and two $(M, N)$ remained 'negative' throughout the study.

Early tests using phosphate-buffered CYE medium showed that $1 \mathrm{~h}$ exposure to 10 p.p.m. QAC/TBTO or to 50 p.p.m. CPh reduced the L. pneumophila count 
Table 5. Action of $Q A C / T B T O$ and $C P h$ on $\mathrm{L}$. pneumophila serogroup 1

$\begin{array}{lccccc} & \begin{array}{c}\text { Concen- } \\ \text { tration } \\ \text { (p.p.m.) }\end{array} & 0 & 1 & 3 & 6 \\ \text { Control } & 0 & 9 \times 10^{8 *} & 2 \times 10^{9} & 7 \times 10^{8} & 1 \times 10^{9} \\ \text { QAC/TBTO } & 5 & 2 \times 10^{9} & 8 \times 10^{8} & 4 \times 10^{8} & 4 \times 10^{8} \\ & 10 & 1 \times 10^{9} & 5 \times 10^{8} & 4 \times 10^{8} & 2 \times 10^{7} \\ & 20 & 8 \times 10^{8} & 1 \times 10^{5} & 3 \times 10^{4} & 1 \times 10^{3} \\ \text { CPh } & 50 & 2 \times 10^{9} & 2 \times 10^{3} & 2 \times 10^{3} & <10^{2} \\ & 10 & 4 \times 10^{8} & 5 \times 10^{8} & 3 \times 10^{8} & 3 \times 10^{5} \\ & 50 & 7 \times 10^{8} & 3 \times 10^{5} & 4 \times 10^{3} & 3 \times 10^{3} \\ & 100 & 1 \times 10^{9} & 4 \times 10^{2} & 8 \times 10^{2} & <10^{2}\end{array}$

* Bacterial count (colony forming units) $/ \mathrm{ml}$ of reaction mixture.

by $4 \log _{10}$ and $3 \log _{10}$, respectively. Later tests after the trial had begun used Aces buffered CYE medium and showed that a greater concentration of QAC/TBTO was required to kill the bacterium (Table 5). Of the two systems treated with QAC/TBTO one (A) remained 'positive' throughout the study while the other, (K) was persistently 'negative'. This treatment did not appear to affect total bacterial counts. L. pneumophila was isolated initially from both systems $(\mathrm{E}, \mathrm{F})$ treated with $\mathrm{CPh}$ but only occasionally during the trial. Total bacterial counts in system $\mathrm{F}$ were reduced temporarily by this biocide. In the two systems treated with $\mathrm{SCl}(\mathrm{B}, \mathrm{L})$ the level of free chlorine fell from 1.2 to $<0.1$ p.p.m. within three days at which time the briquettes had completely dissolved. As there was some delay in reaching cidal levels, a fast-release chlorine preparation was added for the last two treatments which rapidly produced 4 p.p.m. free chlorine and reduced the bacterial count in the post-treatment water samples to $<1 / \mathrm{ml}$. L. pneumophila was isolated from system $B$ before and after this modification of treatment.

Table 6 shows the relationship between the presence of legionellae and the temperature, $\mathrm{pH}$, total dissolved solids and chloride concentration of the fourteen systems. The number of observations above and below the median value of each parameter are grouped according to isolation of $L$. pneumophila. The proportion of observations above the median value of each of the three chemical parameters, and to a lesser extent temperature, were greater in the consistently positive legionella group than in the intermediate or consistently negative groups. For total dissolved solids and chlorides, the differences were highly significant $(P<0.01)$. Water chemistry was studied in more detail on three occasions during the summer. The number of observations was small, but there was a tendency for total hardness, non-carbonate hardness, silica, calcium, nitrate and sulphate concentrations to be higher in those cooling towers from which $L$. pneumophila was always isolated (A-D), than those which were consistently free of legionellae $(\mathrm{K}-\mathrm{N})$. 
J. B. KuRTZ AND OTHERS

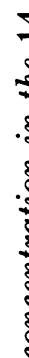

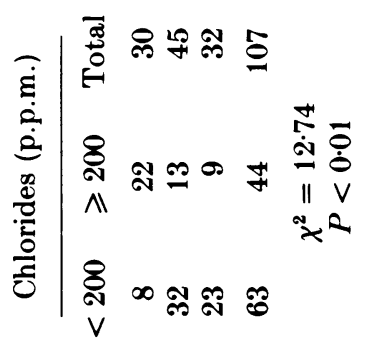

ปัँ

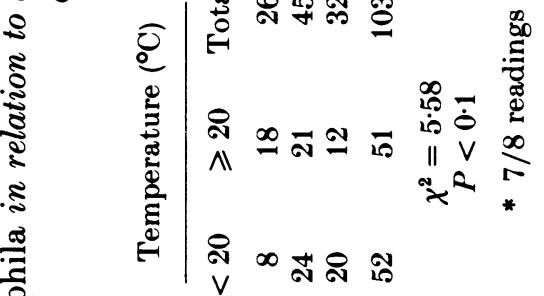

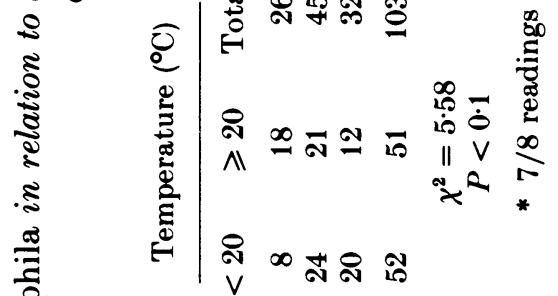

z)

尊富

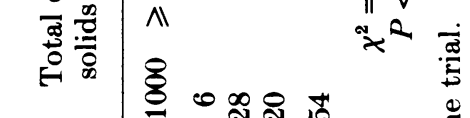

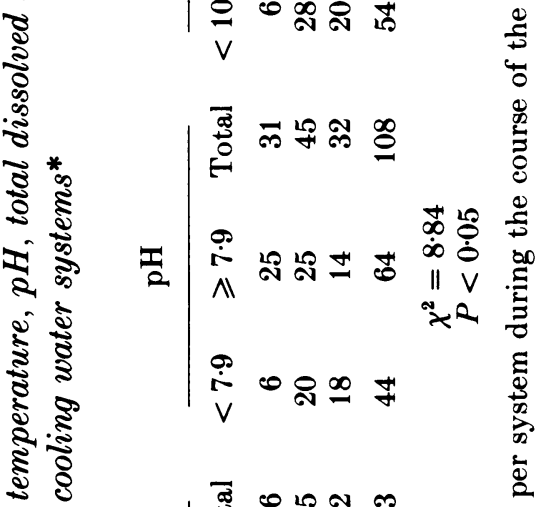

है

ì



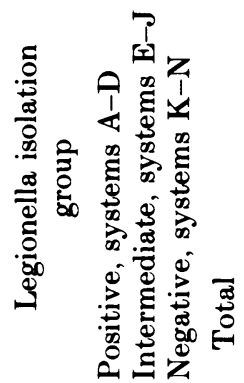




\section{DISCUSSION}

All the cooling towers studied were in central London and derived water ultimately from the same source. Differences in the chemical composition and microbial flora of the water between systems would therefore be due to local factors in the systems themselves or in their immediate environment. The initial survey showed a large variation between towers with respect to their capacities, their conditions and bacterial counts. Some were open to light, others were not. Some had splash bars, others were packed with a PVC honeycomb, which presents a greater surface area on which debris may accumulate. Amoebae were sought because of the suggestion that $L$. pneumophila exists naturally as an intracellular parasite of these protozoa (Rowbotham, 1980). One or more genus of amoebae was isolated from every tower but this ubiquity prevented a positive association from being assessed. The $\mathrm{pH}$ of the pond water of the different systems was in the range 7.5-8.3. In the laboratory L. pneumophila will only grow on a defined medium which is near $\mathrm{pH} \mathrm{6.9}$, but the pond water $\mathrm{pH}$ does not necessarily reflect the $\mathrm{pH}$ in the miro-environment of the slime on surfaces and in the pipes, nor obviously the intracellular $\mathrm{pH}$ of the amoebae, where L. pneumophila might be growing. The lack of an association between legionellae and the presence of algae, which only grow in light, does not support the beneficial relationship between the two suggested by Tison et al. (1980).

An ideal anti-microbial treatment for recirculating cooling water systems should be rapid in action, effective over a wide range of temperatures and $\mathrm{pH}$ and inexpensive. It must be compatible with the other chemicals used to disperse organic matter, and to inhibit scale formation and corrosion. It should meet health and safety requirements and be acceptable to water authorities as suitable for discharge to waste. Finally it should be of acceptable odour and free of foam and scum-producing properties. This trial was designed to study the effect of biocides alone on the bacterial count and on the presence of $L$. pneumophila in the cooling tower waters. No other chemicals were used and therefore the treatment programmes were far from ideal, although perhaps not so far from many routine practices. The programmes were consequently a severe test of biocides.

Several biocides which were effective against $L$. pneumophila in laboratory tests were not included because they did not meet the other criteria mentioned above. At the doses used, based in the case of QAC/TBTO and $\mathrm{CPh}$, on the laboratory results available at the beginning of the trial, the biocides chosen appeared to meet these requirements. In retrospect the dose of QAC/TBTO and the duration of adequate free chlorine levels attained by $\mathrm{SCl}$ were inadequate.

Regular sampling of the eight 'control' cooling towers provided information against which the effect of the various biocides could be judged. Although the number of systems studied was small, the findings suggested that in the absence of treatment a 'positive' tower would remain 'positive' and a 'negative' tower would either continue to be 'negative' or become, and usually stay, 'positive'. This last situation may be dependent on seasonal factors.

The findings in two of the three treatment groups did not differ from the pattern 
of the control systems. In both the QAC/TBTO and the SCl groups there was, at the beginning of the trial, one 'positive' and one 'negative' cooling tower. The status of these four systems was unchanged by treatment and L. pneumophila was even isolated from a sample taken only three days after dosing with $\mathrm{SCl}$ and the fast-release chlorine. The two towers treated with $\mathrm{CPh}$ were both 'positive' initially but L. pneumophila was not isolated from at least one of the three samples taken subsequently from each system. This appeared to be related to the time of sampling after treatment. The organism was not isolated from the two samples, one from each system, taken on the third day, nor from the sample taken on the seventh day after treatment. From all three samples taken 14 days after the previous treatment however, L. pneumophila was isolated. The number of organisms had been temporarily reduced below a detectable level by the $\mathrm{CPh}$ treatment. The succeeding build-up of $L$. pneumophila could have been the result of multiplication of surviving bacteria in the recirculating water, recolonization of the water from the protected depths of slime layers or blind loops, the addition of the organism in the fresh 'make-up' water from a water storage tank, or aerosol drifting from adjacent contaminated towers. More frequent dosing with, or a higher initial concentration of the $\mathrm{CPh}$ may have prevented this recrudescence.

A significant association was found between legionella infection and the concentration of chlorides and total dissolved solids, and a raised $\mathrm{pH}$. The build-up of this matter indicates inadequate 'bleeding' and replacement with fresh water could play an important part in reducing the amount of infection.

The results of this survey did not suggest any association which would give a clear indication of the presence of $L$. pneumophila by the measurement of one or more indicator. Only by seeking the organism itself can its presence be ascertained. At the doses and frequency used the QAC/TBTO and $\mathrm{SCl}$ were ineffective. $\mathrm{CPh}$, however, appeared to have temporarily reduced the number of L. pneumophila below the detectable level. We are studying the effect that frequent or continuous treatment with an effective biocide, combined with efficient bleeding, and anti-scale and anti-corrosion chemicals will have in suppressing and preventing the build-up of $L$. pneumophila in recirculating cooling water systems.

We should like to thank Dr C. S. Robinson, Mr W. T. Dent and Mr R. Ebbes for their technical assistance, and Dr H. Tillett and Miss I-L. Spencer for help with data analysis.

\section{REFERENCES}

Band, J. D., LaVenture, M., Davis, J. P., Mallison, G. F., Skaliy, P., Hayes, P. S., Schell, W. L., Weiss, H., Greennerg, D. J. \& Fraser, D. W. (1981). Epidemic Legionnaires' disease: airborne transmission down a chimney. Journal of the American Medical Association 245, 2404-2407.

Cordes, L. G., Wiesenthal, A. M., Gorman, G. W., Phair, J. P., Sommers, H. M., Brown, A., Yu, V. L., Magnussen, M. H., Meyer, R. D., Wolf, J. S., Shands, K. N. \& Fraser, D. W. (1981). Isolation of Legionella pneumophila from hospital shower heads. Annals of Internal Medicine 94, 195-197. 
Department of the Environment (1972). Analysis of raw potable and waste waters. London: H.M.S.O.

Dondero, T. J., Rendtorff, R. C., Mallison, G. F., Weeks, R. M., Levy, J. S., Wong, E. W. \& SCHAFFNER, W. (1980). An outbreak of Legionnaires' disease associated with a contaminated air-conditioning cooling tower. New England Journal of Medicine 302, 365-370.

Fisher-Hoch, S. P., Bartlett, C. L. R., Tobin, J. O’H., Gillett, M. B., Nelson, A. M., Pritchard, J. E., Smith, M. G., Swann, R. A., Talbot, J. M. \& Thomas, J. A. (1981). Investigation and control of an outbreak of Legionnaires' disease in a district general hospital. Lancet i, 932-936.

Fliermans, C. B., Cherry, W. B., Orrison, L. H. \& Thacker, L. (1979). Isolation of Legionella pneumophila from non-epidemic-related aquatic habitats. Applied and Environmental Microbiology 37, 1239-1242.

Fliermans, C. B., Cherry, W. B., Orrison, L. H., Smith, S. J., Tison, D. L. \& Pope, D. H. (1981). Ecological distribution of Legionella pneumophila. Applied and Environmental Microbiology 41, 9-16.

Grace, R. D., Dewar, N. E., Barnes, W. G. \& Glenn, R. H. (1981). Susceptibility of Legionella pneumophila to three cooling tower microbiocides. Applied and Environmental Microbiology 41, 233-236.

Miles, A. A. \& Misra, S. S. (1938). The estimation of the bactericidal power of the blood. Journal of Hygiene (London) 38, 732-749.

Morris, G. K., Patton, C. M., Feeley, J. C., Johnson, S. E., Gorman, G., Martin, W. T., Skaliy, P., Mallison, G. F., Politi, B. D. \& Mackel, M. S. (1979). Isolation of the Legionnaires' bacterium from environmental samples. Annals of Internal Medicine 90, 664-666.

Pasculle, A. W., Feeley, J. C., Gibson, R. J., Cordes, L. G., Myerowitz, R. L., Patton, C. M., Gorman, G. W., Carmack, C. L., Ezzell, J. W. \& Dowling, J. N. (1980). Pittsburg pneumonia agent: direct isolation from human lung tissue. Journal of Infectious Diseases 141, 727-732.

Rowвотнам, T. J. (1980). Preliminary report on the pathogenicity of Legionella pneumophila for freshwater and soil amoebae. Journal of Clinical Pathology 33, 1179-1183.

Skaliy, P., Thompson, T. A., Gorman, G. W., Morris, G. K., McEachern, H. V. \& Mackel, D. C. (1980). Laboratory studies of disinfectants against Legionella pneumophila. Applied and Environmental Microbiology 40, 697-700.

Tison, D. L., Pope, D. H., Cherry, W. B. \& Fliermans, C. B. (1980). Growth of Legionella pneumophila in association with blue-green algae (Cyanobacteria). Applied and Environmental Microbiology 39, 456-459.

Tobin, J. O'H., Swann, R. A. \& Bartlett, C. L. R. (1981). Isolation of Legionella pneumophila from water systems: methods and preliminary results. British Medical Journal 282, 515-517.

Wang, W. L. L., Blaser, M. J., Cravens, J. \& Johnson, M. A. (1979). Growth, survival and resistance of the Legionnaires' disease bacterium. Annals of Internal Medicine 90, 614-618. 